Poliakova, O.Yu., Shlykova, V.O., and Buntov, I.Yu.

Research Center for Industrial Development Problems, the NAS of Ukraine,

1a, Inzhenernyi Prov., Kharkiv, 61166, Ukraine,

+380 57702 0867, ndc_ipr@ukr.net; https://ndc-ipr.org/

\title{
FORECAST OF BIOTECHNOLOGY TRENDS IN THE WORLD AND IN UKRAINE BASED ON ANALYSIS OF PUBLICATIONS AND PATENTS
}

\begin{abstract}
Introduction. Modern biotechnology is among the top priorities in every advanced economy.
Problem Statement. Successful management of technology development requires an unbiased analysis of scholarly research results and their forecasting. The correspondence of technological development to the world trends plays an important role in ensuring the economy's competitiveness.

Purpose. The purpose of the study is to determine the world trends in scholarly research and developments in the field of biotechnology, as well as the correspondence of the situation in Ukraine to the world trends.

Materials and Methods. Bibliometric and patent analysis is one of the most common tools for analyzing the current state, promising directions of scholarly research and commercial use. This research presents the results of analysis of the world and Ukrainian trends in publication and patent activities in the sphere of biotechnology for 2000-2015, as well as forecasts for 2016-2019. The trend models have been constructed for forecasting. Biotechnology-related publications of SCImago Journal \& Country Rank portal, Science Direct database, and Vernadsky National Library of Ukraine abstract database, as well as patents of the World Intellectual Property Organization database have been used.

Results. The forecast results have shown an upward tendency in the global amount of publications and patents in biotechnology, in the coming years. In all areas of biotechnology, the share of Ukrainian publications in the global space of biotechnological research is extremely small. Among the analyzed areas, the largest forecasted share of Ukrainian origin publications in international databases belongs to Materials Science - Biomaterials and amounts to 0.3\% on the global scale. The patenting of Ukrainian developments at the international level, provided the existing trend is maintained, will also remain at a very low level (0.05\% on a global scale). China and the USA, which have a share of 33.1 and $24.9 \%$, respectively, will keep leadership in this direction The total number of patents belonging to the EU Member States (28) will reach about 18.1\%.

Conclusions. For today, Ukraine has certain advantages in the development of biotechnology in the field of agriculture, which can become the basis for the development of national bioeconomy. Consequently, in the agricultural sector, state support is needed to implement the existing developments by encouraging business. At the same time, in the medical field, there is a significant gap between Ukraine and the leading countries, thus the government should focus efforts on supporting research in this area in order to make its results ready for patenting.
\end{abstract}

Keywords: biotechnology, bibliometrics, patent, correlation, trend, and forecast model.

In Ukraine, the implementation of national research programs in biotechnology is characterized by a low level of commercialization of the results in previous years. Uncertainty in the theory and methods of forming an organizational and

(C) POLIAKOVA, O.Yu., SHLYKOVA, V.O., and BUNTOV, I.Yu., 2019 economic mechanism for the development and commercialization of biotechnology research in Ukraine significantly slows down the formation of the sixth technological structure, does not enable to quickly and effectively increase the competitiveness and investment attractiveness of the country and to reform the Ukrainian economy on this basis as a whole. 
Bibliometric and patent analysis is one of the most common tools for analyzing the current state and promising directions of scientific and commercial development. The close link between scholarly research publications and patent activity is a key to success of science and commercialization of research results.

There is a large number of publications dealing with to various aspects of scholarly research and their links with the practice in the field of biotechnology.

Research on the development of science and technology and their interaction in the field of biotechnology based on bibliometric analysis has been carried out [1] using a specialized abstract database of publications Derwent Biotechnology Abstracts.

The study of publishing activity in the field of bioinformatics has shown the leading role of such countries as the USA, Great Britain, Germany, Japan, India, and China [2]. The highest growth rate of publications in this area has been reported for China and India, despite a short history of research.

The close relationship between scholarly research and patent activity, in particular, for the researchers from academic circles, is shown in [3]. The research focuses on the analysis of citations of scholarly research publications in patents and vice versa, as well as on the patent activity of universities.

The need for the use of bibliometric indicators, especially for assessing the level of scholarly research and achievements in transition economies that undergo structural transformations not only in the economy, but also in the national research and innovation system, has been emphasized in [4]. The author has opposed the objectivity of this approach to certain subjectivity and bias, which are inherited even in anonymous peer review in the case of interdisciplinary research or research in new directions. Using bibliometric indicators allows for greater objectivity in research and engineering policy in the case of limited resources.
Scientometric analysis is used to analyze the positioning of countries in the world scientific and technological space and to identify the advantages and underdeveloped areas in the field of biotechnology. In particular, a detailed analysis of the citation indices of the works of Russian researchers as compared with researchers from the United States and China has been carried out in [5], which enables to identify chemistry and materials science as the most advanced areas of biotechnological research.

The importance of bibliometric and patent analysis to assess the R\&D in new areas has been underlined in [6], where a detailed analysis of existing approaches and indicators used in the development of nanotechnology research has been made. Similarly, bibliometric and patent analysis has been used in [7] to identify directions and structure and to evaluate the interpenetration of biotechnological R\&D in food industry, which makes it possible to reveal an increase in the concentration of developments in narrow areas of expertise in the EU and the USA, despite interdisciplinarity of biotechnology.

The prospects of bibliometric analysis for assessing the trends in scholarly research and their impact by example of biotechnological developments in pharmaceuticals has been shown in [8]. International communications and cooperation in the field of biopharmaceutical developments are the subject of bibliometric analysis [9] that shows the close links between research conducted by TNCs from the USA, the EU and others in this area.

The patent analysis is used as a quantitative approach to the technology analysis in order to avoid unsustainable results that often occur with the use of qualitative approaches such as Delphi expert surveys, scenario analysis, road mapping, where results can be subjective and dependent on knowledge and experience of individual expert. The patent is one of the sources of objective data, and the technology analysis is an important aspect of technology management. In turn, the research and engineering policy depends on the results of the technology analysis [10]. 
An important advantage of the patent research is the openness of patent documents and the completeness of the technical component [10].

J. Choi, S. Jun, and S. Park use patent analysis to manage sustainable technologies that provide technological competitiveness and economic growth both for the country as a whole and for individual corporations [10]. Scholars offer their own approach to the patent analysis in order to identify sustainable technologies, which consists in building a diagram of the hierarchy of technologies by finding the causal relationships between the technology keywords [10].

The research by H. Noh, Y. Jo, and S. Lee deals with strategic approaches to keyword analysis for further application of text-mining to patent data. The authors solve the following tasks: what element of the patent documentation should be used to select a keyword; which methods of choosing a keyword should be used; how many keywords should be chosen; how to convert a keyword into a format suitable for data analysis [11].

In addition, research is being conducted to develop a methodology for estimating the value of corporate patent portfolios for strategic planning and technology management [12].

S. Kortov with coauthors analyzes the patent landscapes in the field of 3D-printing in general and in its individual areas: additive machines, selective laser sintering of ceramic materials, fusion of material in a pre-formed layer [13]. Within the framework of the proposed methodology, the analysis of patent landscapes concerning promising technologies for the development in a specific region has been carried out.

Sunghae J., Sang Sung P., and Dong Sik J. have proposed a method for forecasting technologies based on various techniques of patent data analysis [14]. The research is based on patent documentation in the areas related to biotechnology. The authors use the time series analysis (ARIMA) to study the dynamics of the total number of patents related to biotechnology (in accordance with the WIPO International Patent Classification Co- de), the association rule (ARM), and clustering of patents.

In [15], the authors have studied patents developed in Ukraine on the basis of information from the specialized database Inventions (Utility Models) in Ukraine of the Ukrainian Institute of Intellectual Property [16]. For the analysis of patents in the field of biotechnology, the search in the database was carried out by WIPO International Patent Classification Code, which according to the table of correspondence of technologies relate to biotechnology.

Thus, the analysis of patent information is an approach that often used to identify trends, competitive advantages, strengths, and weaknesses in technology at the macro-, meso-, and micro- levels. In the complex, bibliometric and patent analysis is a key tool for identifying the most promising areas of research and commercialization of research results.

The purpose of this research is to determine the world trends in biotechnology R\&D, as well as the correspondence of the situation in Ukraine to the world trends.

The task of this research is to analyze the state and to forecast the scale of scientific and technical support for the development of biotechnology in Ukraine and in the world based on data about the publication and patent activities.

\section{THE MAIN BODY OF THE RESEARCH}

The analysis of publishing activity has been carried out in the context of separate scholarly research directions and knowledge branches in biotechnology. The patent activity has been studied only for biotechnology as a whole. The time series covered the period of 2000-2015. The publication and patent activities have been built on the global scale, distinguishing leading countries by the number of publications and patents, as well as for Ukraine. Parameters and characteristics of trend models have been calculated using software package Statistica 8.0. The determination coefficient $\left(\mathrm{R}^{2}\right)$ is used to assess the adequacy of the obtained equations, the significance of 
the coefficients in the equations has been determined using the Student (St) and Fisher (F) statistics, and the mean absolute percent error (MAPE) as a measure of forecast accuracy has been calculated.

The data of SCImago Journal E Country Rank portal [17] was used to analyze the publishing activity of the world countries and to identify promising areas for research in biotechnology and related areas. The results of this analysis have made it possible to identify those countries where the most active biotechnology research is carried out and to determine the most promising areas of research. The analysis has been conducted in the biotechnology subject area and is related to the following:

+ biochemistry, genetics and molecular biology biotechnology;
+ chemical engineering - bioengineering;

+ engineering - biomedical engineering;

+ immunology and microbiology - applied microbiology and biotechnology; and

+ materials science - biomaterials.

The dynamics of the number of publications in the whole world is best described by the following logistic trend:

$$
\begin{gathered}
y_{\text {World }}^{\text {biotech }}(t)=14502.14 /\left(0.366+\exp \left(-0.193^{*} t\right),\right. \\
R^{2}=0.97 ; S t_{1}=10.40 ; S t_{2}=9.62 ; S t_{3}=-6.14 ; \\
F=1347.98 ; M A P E=5.8 \%
\end{gathered}
$$

where $t$ is time, $t=0$ corresponds to 2000 year. The confidence level in this and all subsequent models is, at least, 0.05 , unless otherwise specified.

The number of publications in biotechnology within the framework of related biochemistry, ge-

Trend Models of the Number of New Publications in Biochemistry,

\begin{tabular}{|c|c|}
\hline Country & Model \\
\hline United Kingdom & $\begin{array}{c}\mathrm{Y}_{\text {United Kingdom }}^{\text {biotech }}(t)=873.3015+54.3765 \cdot t \\
R^{2}=0.92 ; S t_{1}=22.77 ; S t_{2}=12.49 ; F=155.89 ; M A P E=5.3 \%\end{array}$ \\
\hline Germany & $\begin{array}{c}\mathrm{Y}_{\text {Germany }}^{\text {biotech }}(t)=1104.78 /(0.494+\exp (-0.236 \cdot t)) \\
R^{2}=0.97 ; S t_{1}=11.07 ; S t_{2}=11.64 ; S t_{3}=-7.74 ; F=2100.93 ; M A P E=5.0 \%\end{array}$ \\
\hline Total for the EU countries & $\begin{array}{c}\mathrm{Y}_{\mathrm{EU}}^{\text {biotech }}(t)=6269.71 /(0.445+\exp (-0.155 \cdot t)) \\
R^{2}=0.98 ; S t_{1}=17.42 ; S t_{2}=9.28 ; S t_{3}=-6.55 ; F=2690.64 ; M A P E=4.0 \%\end{array}$ \\
\hline India & $\begin{array}{c}\left.\mathrm{Y}_{\text {India }}^{\text {biotech }}(t)=632.83 \cdot \exp (0.1178 \cdot t)\right) \\
R^{2}=0.91 ; S t_{1}=11.90 ; S t_{2}=16.97 ; F=844.25 ; M A P E=7.9 \%\end{array}$ \\
\hline China & $\begin{array}{c}\mathrm{Y}_{\text {China }}^{\text {biotech }}(t)=176.52 /(0.0245+\exp (-0.4464 \cdot t)) \\
R^{2}=0.96 ; S t_{1}=1.79,(p<0.1) ; S t_{2}=1.95,(p<0.1) ; S t_{3}=-5.73 ; F=305.91 ; M A P E=12 \%\end{array}$ \\
\hline Korea & $\begin{array}{c}\mathrm{Y}_{\text {Korea }}^{\text {biotech }}(t)=509.98 /(0.1771+\exp (-0.1886 \cdot t)) \\
R^{2}=0.98 ; S t_{1}=10.78 ; S t_{2}=9.32 ; S t_{3}=-7.87 ; F=1503.39 ; M A P E=6.4 \%\end{array}$ \\
\hline USA & $\begin{array}{c}\mathrm{Y}_{\mathrm{USA}}^{\text {biotech }}(t)=3753.87 /(0.517+\exp (-0.219 \cdot t)) \\
R^{2}=0.93 ; S t_{1}=7.01 ; S t_{2}=7.13 ; S t_{3}=-4.37 ; F=767.20 ; M A P E=5.4 \%\end{array}$ \\
\hline Japan & $\begin{array}{c}\mathrm{Y}_{\text {Japan }}^{\text {biotech }}(t)=-6.231 \cdot t^{2}+122.034 \cdot t+1511.154 \\
R^{2}=0.68 ; S t_{1}=-3.49 ; S t_{2}=4.39 ; S t_{3}=16.85 ; F=1117.17 ; M A P E=5.9 \%\end{array}$ \\
\hline Ukraine & $\mathrm{Y}_{\text {Ukraine }}^{\text {biotech }}(t)=\mathrm{RND} \mathrm{N}(28.31 ; 16.25)$ \\
\hline Total in the world & $\begin{array}{c}\mathrm{Y}_{\text {World }}^{\text {biotech }}(t)=14502.14 /(0.366+\exp (-0.193 \cdot t)) \\
R^{2}=0.97 ; S t_{1}=10.40 ; S t_{2}=9.62 ; S t_{3}=-6.14 ; F=1347.98 ; M A P E=5.8 \%\end{array}$ \\
\hline
\end{tabular}

Table 1 Genetics, and Molecular Biology - Biotechnology

Information is taken from authors' sources. 
netics and molecular biology in all world countries was constantly increasing in 2000-2015 [17].

A slight decrease in the number of publications was reported in 2010, which most likely was a late effect of the 2007-2008 global financial crisis. The fall in 2015 in this direction, as in other areas considered, was caused by a delay in the processing of publications.

For 16 years, the average annual growth rate of the world publications was $6.6 \%$. The biotechnology research was most rapidly developing in 2004-2009. Since 2009, the growth rate has decreased, which may be a result of suspended research during the crisis period. Thus, it can be stated that in the world, there is a constant scientific interest in biotechnology.

According to the analysis of the dynamics of publications by countries in biotechnology, the number of publications in China has been growing at the highest pace, so from 2013, China has overtaken the USA that was the previous leader in this direction. A growth is reported for almost all countries, except Japan, where the number of publications tends to decrease starting with 2010.

The obtained models for the studied field of biotechnology are presented in Table 1.

The forecasted number of scholarly research publications in the studied field in the world leading countries are presented in Table 2. According to the results, China is slightly ahead of the USA in terms of its share in publications. Altogether $86.4 \%$ of publications belong to the
EU, the USA, China, and India. The share of Ukraine will not increase and remain very low (0.1\%), which indicates the need to take measures for stimulating research in this direction.

It should be noted that during 2008-2010, in all leading countries, there were reported some changes in the rate of growth in the number of new publications. However, attempts to take into account this fact with the help of dummy variables did not significantly improve the quality characteristics of predictive models, since the period after the shifts is too short. Therefore, in the further study, models were used for the entire time period without dividing it into sub-periods.

The dynamics of the number of publications from Ukraine do not show a stable tendency (Table 3), but a significant growth is noted in 2006 (44 against 14 in the previous year) and in 2007 (66 publications).

In general, since 2006, the average annual number of publications has increased in comparison with 2000-2005, but remains small. Therefore, it was not possible to build an adequate trend model for publications on biotechnology in Ukraine. For the purpose of forecasting, the random values of parameters measured at the original data applied.

In the field of chemical engineering, the analysis included bioengineering publications. The annual growth rate of the world publications for the analyzed period of 16 years was $10.2 \%$. Like in biotechnology, the highest growth rate was ob-

Forecast of the Number of Publications in Biochemistry,

Table 2 Genetics, and Molecular Biology - Biotechnology

\begin{tabular}{|c|c|c|c|c|c|c|c|c|c|c|}
\hline Years & $\begin{array}{c}\text { United } \\
\text { Kingdom }\end{array}$ & Germany & $\begin{array}{c}\text { Total for the } \\
\text { EU countries }\end{array}$ & India & China & Korea & USA & $\begin{array}{c}\text { Japan } \\
\text { Ukraine }\end{array}$ & $\begin{array}{c}\text { Total in the } \\
\text { world }\end{array}$ \\
\hline 2016 & 1743 & 2137 & 11858 & 4167 & 6980 & 2256 & 6862 & 1869 & 19 & 35234 \\
2017 & 1798 & 2157 & 12134 & 4688 & 7059 & 2344 & 6937 & 1785 & 23 & 35933 \\
2018 & 1852 & 2174 & 12380 & 5274 & 7111 & 2421 & 6998 & 1689 & 61 & 36530 \\
2019 & 1906 & 2186 & 12600 & 5934 & 7144 & 2489 & 7048 & 1580 & 14 & 37037 \\
\end{tabular}

Information is taken from authors' sources. 
Dynamics of the Number of International Publications

from Ukraine Based on the Data scimagjr.com Portal

\begin{tabular}{|l|c|c|c|c|c|c|c|c|c|c|c|c|c|c|c|c|}
\hline \multicolumn{1}{|c|}{ Field } & \multicolumn{10}{|c|}{ Years } \\
\cline { 2 - 13 } & 2000 & 2001 & 2002 & 2003 & 2004 & 2005 & 2006 & 2007 & 2008 & 2009 & 2010 & 2011 & 2012 & 2013 & 2014 & 2015 \\
\hline $\begin{array}{l}\text { Biochemistry, genetics, } \\
\text { and molecular biology - } \\
\text { biotechnology } \\
\begin{array}{l}\text { Chemical engineering - } \\
\text { bioengineering }\end{array}\end{array}$ & 13 & 14 & 13 & 12 & 15 & 14 & 44 & 66 & 22 & 42 & 18 & 40 & 26 & 43 & 45 & 26 \\
$\begin{array}{l}\text { Engineering - biomedi- } \\
\text { cal engineering }\end{array}$ & 8 & 12 & 10 & 6 & 13 & 16 & 27 & 24 & 38 & 38 & 29 & 33 & 36 & 40 & 53 & 42 \\
$\begin{array}{l}\text { Immunology and micro- } \\
\text { biology - applied mic- } \\
\text { robiology and biotech- } \\
\text { nology } \\
\begin{array}{l}\text { Material science - bio- } \\
\text { materials }\end{array}\end{array}$ & 21 & 20 & 10 & 8 & 6 & 18 & 11 & 19 & 28 & 26 & 22 & 34 & 35 & 31 & 33 & 35 \\
\hline
\end{tabular}

Trend Models of the Number of New Publications in Chemical Engineering - Bioengineering

\begin{tabular}{|c|c|}
\hline Country & Model \\
\hline United Kingdom & $\begin{array}{c}\mathrm{Y}_{\text {United Kingdom }}^{\text {bioeng }}(t)=410.42 /(0.336+\exp (-0.317 \cdot t)) \\
R^{2}=0.90 ; S t_{1}=4.04 ; S t_{2}=4.37 ; S t_{3}=-4.47 ; F=411.02 ; M A P E=7.4 \%(2005-2015)\end{array}$ \\
\hline Germany & $\begin{array}{c}\mathrm{Y}_{\text {Germany }}^{\text {bioeng }}(t)=212.71 /(0.145+\exp (-0.399 \cdot t)) \\
R^{2}=0.88 ; S t_{1}=2.20 ; S t_{2}=2.36 ; S t_{3}=-3.97 ; F=200.41 ; M A P E=10.0 \%(2005-2015)\end{array}$ \\
\hline Total for the EU countries & $\begin{array}{c}\mathrm{Y}_{\mathrm{EU}}^{\text {bioeng }}(t)=1518.69 /(0.176+\exp (-0.326 \cdot t)) \\
R^{2}=0.95 ; S t_{1}=4.18 ; S t_{2}=4.67 ; S t_{3}=-6.12 ; F=528.20 ; M A P E=8.1 \%(2005-2015)\end{array}$ \\
\hline India & $\begin{array}{c}\mathrm{Y}_{\text {India }}^{\text {bioeng }}(t)=133.09 /(0.056+\exp (-0.299 \cdot t)) \\
R^{2}=0.99 ; S t_{1}=4.82 ; S t_{2}=6.27 ; S t_{3}=-9.31 ; F=945.58 ; M A P E=8.5 \%(2005-2015)\end{array}$ \\
\hline China & $\begin{array}{c}Y_{\text {China }}^{\text {bioeng }}(t)=224.82 /(0.0277+\exp (-0.3120 \cdot t)), \\
R^{2}=0.99 ; S t_{1}=5.09 ; S t_{2}=7.16 ; S t_{3}=-11.93 ; F=1467.81 ; M A P E=9.5 \%(2005-2015)\end{array}$ \\
\hline Korea & $\begin{array}{c}\mathrm{Y}_{\text {Korea }}^{\text {bioeng }}(t)=91.82 /(0.0387+\exp (-0.383 \cdot t)) \\
R^{2}=0.98 ; S t_{1}=3.21 ; S t_{2}=3.66 ; S t_{3}=-8.44 ; F=683.24 ; M A P E=8.6 \%(2005-2015)\end{array}$ \\
\hline USA & $\begin{array}{c}\mathrm{Y}_{\mathrm{USA}}^{\mathrm{bioeng}}(t)=1087.439 /(0.179+\exp (-0.364 \cdot t)) \\
R^{2}=0.91 ; S t_{1}=3.01 ; S t_{2}=3.26 ; S t_{3}=-4.71 ; F=312.09 ; M A P E=10.8 \%(2005-2015)\end{array}$ \\
\hline Japan & $\begin{array}{c}\mathrm{Y}_{\text {Japan }}^{\text {biong }}(t)=1085.644 /(0.749+\exp (-0.290 \cdot t)) \\
R^{2}=0.71 ; S t_{1}=-3.23 ; S t_{2}=3.34 ; S t_{3}=-2.38 ; F=252.84 ; M A P E=9.0 \%(2001-2015)\end{array}$ \\
\hline Ukraine & $\begin{array}{c}\mathrm{Y}_{\text {Ukraine }}^{\text {biong }}(t)=5.5588+2.8088 \cdot t \\
R^{2}=0.86 ; D W=1.739 ; F=89.13 ; M A P E=14.2 \%(2005-2015)\end{array}$ \\
\hline Total in the world & $\begin{array}{c}\mathrm{Y}_{\text {World }}^{\text {bioeng }}(t)=5151.459 /(0.176+\exp (-0.273 \cdot t)) \\
R^{2}=0.97 ; S t_{1}=6.20 ; S t_{2}=7.36 ; S t_{3}=-7.74 ; F=922.33 ; M A P E=8.4 \%(2005-2015)\end{array}$ \\
\hline
\end{tabular}

Information is taken from authors' sources. 
served in 2005-2009. Since 2010, the number of publications grew much slower, and in 2010 and 2014, even decreased. To a large extent, the latest decline is caused by a fall in the number of publications in 2014 in Israel, Korea, the United States, and in Japan. In Japan, the downward trend began in 2010. Among the EU countries, the most significant decline (by $20.1 \%$, as compared to the highest rate in 2010) was recorded in the UK.

Unlike in the previous area, it can be stated that in bioengineering, in Ukraine, there is a weak upward trend in the number of international publications. Since 2006, it fell only in the post-crisis period of 2010 and, in general, has been growing.

Due to a rapid growth, in 2014, China surpassed the USA that was a permanent leader by the number of publications.

The developed trend models and their qualitative characteristics are shown in Table. 4. In some cases where the largest deviations are observed at the beginning of the period under consideration, a shorter time interval, as indicated in the brackets, is used to calculate the average percentage error.

The results of forecasting show that China will keep leading in the future (Table 5). The total share of China, the USA, and EU is $77 \%$, which indicates a greater diversification of research in this area in the world and offers more opportunities for cooperation with Ukrainian scholars. As a positive trend, it should be noted that the share of Ukrainian publications (from $0.14 \%$ to $0.2 \%$ ) has increased insignificantly but still remains small.
The biomedical engineering direction shows similar dynamic to the above mentioned fields. The largest increase was reported for 2005-2009, the further growth was slow, and in 2012, the global number of publications in this area temporarily decreased. The average growth rate of publications in the world for the entire period under review amounted to $9.8 \%$ annually.

The number of publications from Ukraine almost did not change in 2000-2004, thereafter it is growing slowly, but this trend is not stable. In the world leading countries, the upward trend has not been interrupted.

In the leading countries, the most frequently, the upward dynamics in the number of new publications in biomedical engineering are described by logistic trend. However, in some cases, the best result was obtained using other models. The developed models and their characteristics are shown in Table 6.

According to the forecast results, the number of publications in biomedical engineering (Table 7), it can be noted that the USA, EU, and China will keep their leading positions in this direction (together they hold a share of $79.5 \%$ ). The share of Ukraine in the world publications will double, which can be considered a positive trend, since the growth rate will be slightly higher than that in the leading countries. However, this share will remain low.

The smallest number of publications in the world among the considered areas related to bio-

Forecast of Publications in Chemical Engineering - Bioengineering

\begin{tabular}{c|c|c|c|c|c|c|c|c|c|c|}
\hline Years & $\begin{array}{c}\text { United } \\
\text { Kingdom }\end{array}$ & Germany & $\begin{array}{c}\text { Total for the } \\
\text { EU countries }\end{array}$ & India & China & Korea & USA & Japan & Ukraine & $\begin{array}{c}\text { Total in the } \\
\text { world }\end{array}$ \\
\hline 2016 & 1199 & 1450 & 8371 & 2068 & 6518 & 2246 & 5976 & 1431 & 50 & 27303 \\
2017 & 1205 & 1456 & 8441 & 2140 & 6881 & 2285 & 6006 & 1436 & 53 & 27749 \\
2018 & 1210 & 1459 & 8492 & 2196 & 7174 & 2312 & 6027 & 1439 & 56 & 28097 \\
2019 & 1213 & 1462 & 8530 & 2240 & 7404 & 2331 & 6042 & 1442 & 59 & 28369 \\
\\
\end{tabular}

Information is taken from authors' sources. 
technology falls on applied microbiology and biotechnology, within the scope of immunology and microbiology.

The upward trend prevailed in 2000-2011. Further, the situation was almost stabilized, with no breakthrough research in this direction reported in the world. The annual growth rate of publications in the world is $3.8 \%$.

The fastest growth in the number of publications was observed in China, from 90, in 2000, to

Trend Models of the Number of New Publications

Table 6 in Engineering - Biomedical Engineerin

\begin{tabular}{|c|c|}
\hline Country & Model \\
\hline United Kingdom & $\begin{array}{c}\mathrm{Y}_{\text {United Kingdom }}^{\text {biomeding }}(t)=341.509 /(0.175+\exp (-0.283 \cdot t)) \\
R^{2}=0.95 ; S t_{1}=4.69 ; S t_{2}=5.50 ; S t_{3}=-6.07 ; F=553.58 ; M A P E=7.6 \%(2004-2015)\end{array}$ \\
\hline Germany & $\begin{array}{c}\begin{array}{c}Y_{\text {Germany }}^{\text {bioming }} \\
\text { ( }\end{array}(t)=280.754 /(0.139+\exp (-0.299 \cdot t)) \\
R^{2}=0.90 ; S t_{1}=2.72 ; S t_{2}=3.19 ; S t_{3}=-4.03 ; F=215.12 ; M A P E=12.0 \%(2005-2015)\end{array}$ \\
\hline Total for the EU countries & $\begin{array}{c}\mathrm{Y}_{\mathrm{EU}}^{\text {biomeding }}(t)=1501.401 /(0.124+\exp (-0.293 \cdot t)) \\
R^{2}=0.97 ; S t_{1}=4.99 ; S t_{2}=5.97 ; S t_{3}=-7.55 ; F=735.62 ; M A P E=7.4 \%(2003-2015)\end{array}$ \\
\hline India & $\begin{array}{c}\mathrm{Y}_{\text {India }}^{\text {bioming }}(t)=172.809 \cdot t-741.909 \\
R^{2}=0.98 ; S t_{1}=9.01 ; S t_{2}=94.46 ; F=368.12 ; M A P E=8.4 \%(2005-2015)\end{array}$ \\
\hline China & $\begin{array}{c}\mathrm{Y}_{\text {China }}^{\text {biomeding }}(t)=5374.744 \cdot t-6714.1 \\
R^{2}=0.71 ; S t_{1}=1086.9 ; S t_{2}=-2405.4 ; F=24.14 ; M A P E=18.1 \%\end{array}$ \\
\hline Korea & $\begin{array}{c}\mathrm{Y}_{\text {Korea }}^{\text {biomeding }}(t)=74.751 /(0.0339+\exp (-0.385 \cdot t)) \\
R^{2}=0.98 ; S t_{1}=2.99 ; S t_{2}=3.43 ; S t_{3}=-8.15 ; F=630.00 ; M A P E=10.5 \%(2001-2015)\end{array}$ \\
\hline USA & $\begin{array}{c}\mathrm{Y}_{\mathrm{USA}}^{\text {biomeding }}(t)=1917.804 /(0.207+\exp (-0.256 \cdot t)) \\
R^{2}=0.94 ; S t_{1}=4.71 ; S t_{2}=5.57 ; S t_{3}=-5.14 ; F=464.48 ; M A P E=7.4 \%(2004-2015)\end{array}$ \\
\hline Japan & $\begin{array}{c}\mathrm{Y}_{\text {Japan }}^{\text {biomeding }}(t)=584.68 /(0.285+\exp (-0.201 \cdot t)), \\
R^{2}=0.85 ; S t_{1}=-3.95 ; S t_{2}=3.97 ; S t_{3}=-2.73 ; F=210.86 ; M A P E=12.5 \%(2001-2015)\end{array}$ \\
\hline Ukraine & $\begin{array}{c}\mathrm{Y}_{\text {Ukraine }}^{\text {biomeding }}(t)=8.764 \cdot \exp (0.105 \cdot t) \\
R^{2}=0.81 ; S t_{1}=5.80 ; S t_{2}=6.65 ; F=166.76 ; M A P E=24.2 \%(2000-2014)\end{array}$ \\
\hline Total in the world & $\begin{array}{c}\mathrm{Y}_{\text {World }}^{\text {biomeding }}(t)=3072.305 /(0.083+\exp (-0.390 \cdot t)) \\
R^{2}=0.96 ; S t_{1}=3.10 ; S t_{2}=3.40 ; S t_{3}=-6.66 ; F=478.80 ; M A P E=15.0 \%\end{array}$ \\
\hline
\end{tabular}

Information is taken from authors' sources.

Forecast of the Number of Publications in Engineering - Biomedical Engineering

\begin{tabular}{|c|c|c|c|c|c|c|c|c|c|c|}
\hline Years & $\begin{array}{c}\text { United } \\
\text { Kingdom }\end{array}$ & Germany & $\begin{array}{c}\text { Total for the } \\
\text { EU countries }\end{array}$ & India & China & Korea & USA & Japan & Ukraine & $\begin{array}{c}\text { Total in the } \\
\text { world }\end{array}$ \\
\hline 2016 & 1838 & 1905 & 11271 & 2023 & 8188 & 2076 & 8575 & 1798 & 47 & 36166 \\
2017 & 1865 & 1934 & 11473 & 2196 & 8514 & 2115 & 8722 & 1840 & 52 & 36436 \\
2018 & 1885 & 1955 & 11628 & 2369 & 8821 & 2143 & 8839 & 1875 & 58 & 36621 \\
2019 & 1901 & 1971 & 11746 & 2541 & 9112 & 2163 & 8932 & 1905 & 64 & 36747 \\
\end{tabular}

Information is taken from authors' sources. 
3482, in 2014. Thanks to such a rapid growth, China overtook the USA in the number of publications in this direction since 2008 and has been keeping its leadership so far. In almost all countries, the number of publications is by an order of magnitude smaller as compared with that in the other directions. A decline in the global number of publications is caused mainly by a drop in this indicator in the United Kingdom, Turkey, and in Switzerland.

Trend Models of the Number of New Publications in Immunology

Table 8 and Microbiology - Applied Microbiology and Biotechnology (IMAMB)

\begin{tabular}{|c|c|}
\hline Country & Model \\
\hline United Kingdom & $\begin{array}{c}\mathrm{Y}_{\text {United Kingdom }}^{\mathrm{IMAMB}}(t)=484.507 \cdot \exp (-0.0172 \cdot t) \\
R^{2}=0.51 ; S t_{1}=27.10 ; S t_{2}=-3.81 ; F=1171.82 ; M A P E=6.6 \%\end{array}$ \\
\hline Germany & $\begin{array}{c}\mathrm{Y}_{\text {Germany }}^{\mathrm{IMAMB}}(t)=398.444 \cdot \exp (0.0441 \cdot t) \\
R^{2}=0.84 ; S t_{1}=19.18 ; S t_{2}=8.72 ; F=1012.21 ; M A P E=7.3 \%\end{array}$ \\
\hline Total for the EU countries & $\begin{array}{c}\mathrm{Y}_{\mathrm{EU}}^{\mathrm{IMAMB}}(t)=2562.944 \cdot \exp (0.031 \cdot t) \\
R^{2}=0.86 ; S t_{1}=30.24 ; S t_{2}=9.22 ; F=2202.37 ; M A P E=4.9 \%\end{array}$ \\
\hline India & $\begin{array}{c}\mathrm{Y}_{\text {India }}^{\operatorname{IMAMB}}(t)=248.308 /(0.1967+\exp (-0.3304 \cdot t)) \\
R^{2}=0.95 ; S t_{1}=4.23 ; S t_{2}=4.68 ; S t_{3}=-6.00 ; F=531.84 ; M A P E=9.0 \%\end{array}$ \\
\hline China & $\begin{array}{c}\mathrm{Y}_{\text {China }}^{\mathrm{IMAMB}}(t)=42.0883 /(0.0129+\exp (-0.5725 \cdot t)), \\
R^{2}=0.98 ; S t_{1}=2.12 ; S t_{2}=2.21 ; S t_{3}=-8.60 ; F=730.12 ; M A P E=10.9 \%(2002-2015)\end{array}$ \\
\hline Korea & $\begin{array}{c}\mathrm{Y}_{\text {Korea }}^{\text {IMАмB }}(t)=496.233 /(0.3727+\exp (-0.235 \cdot t)) \\
R^{2}=0.92 ; S t_{1}=5.56 ; S t_{2}=6.08 ; S t_{3}=-4.35 ; F=525.24 ; M A P E=7.8 \%\end{array}$ \\
\hline USA & $\begin{array}{c}\mathrm{Y}_{\mathrm{USA}}^{\mathrm{IMAMB}}(t)=-4.456 \cdot t^{2}+110.557 \cdot t+1181.255 \\
R^{2}=0.87 ; S t_{1}=-3.64 ; S t_{2}=5.82 ; S t_{3}=19.22 ; F=1762.61 ; M A P E=4.3 \%\end{array}$ \\
\hline Japan & $\begin{array}{c}\mathrm{Y}_{\mathrm{Japan}}^{\mathrm{IMAMB}}(t)=-0.403 \cdot t^{3}+5.362 \cdot t^{2}+1013.468 \\
R^{2}=0.81 ; S t_{1}=-6.92 ; S t_{2}=6.307 ; S t_{3}=51.68 ; F=3637.25 ; M A P E=2.7 \%\end{array}$ \\
\hline Ukraine & $\begin{array}{c}\mathrm{Y}_{\text {Ukraine }}^{\mathrm{IMAMB}}(t)=13.60+0.6 \cdot t \\
R^{2}=0.78 ; S t_{1}=7.69 ; S t_{2}=3.57 ; F=126.77 ; M A P E=7.6 \%(2004-2015 \text { with out } 2010)\end{array}$ \\
\hline Total in the world & $\begin{array}{c}\mathrm{Y}_{\text {World }}^{\mathrm{IMAMB}}(t)=9532.244 /(0.593+\exp (-0.184 \cdot t)) \\
R^{2}=0.92 ; S t_{1}=8.31 ; S t_{2}=6.86 ; S t_{3}=-3.82 ; F=865.85 ; M A P E=5.9 \%\end{array}$ \\
\hline
\end{tabular}

Information is taken from authors' sources.

Forecast of Publications in Immunology and Microbiology - Applied Microbiology and Biotechnology

Table 9

\begin{tabular}{|c|c|c|c|c|c|c|c|c|c|c|}
\hline Years & $\begin{array}{c}\text { United } \\
\text { Kingdom }\end{array}$ & Germany & $\begin{array}{l}\text { Total for the } \\
\text { EU countries }\end{array}$ & India & China & Korea & USA & Japan & Ukraine & $\begin{array}{c}\text { Total in the } \\
\text { world }\end{array}$ \\
\hline 2016 & 368 & 807 & 4209 & 1231 & 3236 & 1253 & 1809 & 735 & 23 & 14764 \\
\hline 2017 & 362 & 843 & 4341 & 1239 & 3248 & 1269 & 1773 & 583 & 24 & 14969 \\
\hline 2018 & 356 & 881 & 4478 & 1246 & 3254 & 1281 & 1728 & 400 & 24 & 15144 \\
\hline 2019 & 349 & 921 & 4619 & 1250 & 3258 & 1292 & 1673 & 185 & 25 & 15293 \\
\hline \multicolumn{11}{|c|}{ Share for $2016-2019$} \\
\hline & 2.4 & 5.7 & 29.3 & 8.3 & 21.6 & 8.5 & 11.6 & 3.2 & 0.2 & \\
\hline
\end{tabular}

Information is taken from authors' sources. 
The dynamics of publications in Ukraine in applied microbiology and biotechnology (Table 3) show a negative trend. A very slow growth in 2000-2004 was interrupted in 2005, and during 2005-2010, the number of publications in this direction was almost constantly half the value for the previous period. In 2011-2015, the number of publications slightly increased, but did not reach the level of 2004. This indicates an unsatisfactory development of research on applied biotechnology directions in the country.

To forecast the number of publications in immunology and microbiology - applied microbiology and biotechnology, trend models were developed. They are shown in Table 8.

The results of the forecast in Table 9 indicate an enhancement of China's role in developing this direction of research (21.6\% vs. $29.3 \%$ in the EU countries). The share of Ukraine in the world publications will increase slightly to $0.2 \%$. This small value indicates the need to support research in the field of applied biotechnology.

The analysis of dynamics of the number of world publications in materials science - biomaterials has showed a significant growth rate for $2000-2015$, which has an average of $8.8 \%$ annually. The maximum growth occurred in 2008 . Such an essential growth rate is mainly provided by researchers from China and the USA. Starting with 2014, China is ahead of the USA by the number of publications in this direction.

The biomaterials direction is the only one that has not undergone a slowdown in the number of publications. In general, unlike the others directions, the number of publications in the world in this field is subject to a linear trend with a determination coefficient of $95.8 \%$. That is, in the world, there is a constant scientific interest in issues related to the development, properties, and use of biomaterials. Such interest is supported in all countries under review, the largest boom of publications was observed in 2008 as their numbers grew by $41.8 \%$. The following fall lasted for a short while, and the level of 2008 was regained in 2011. However, in general, the total number of world publications in biomaterials for 2000-2015 was less almost by a quarter (24.7\%) than that in applied microbiology and biotechnology for the same period. However, due to the current trend with a constant rate, in 2015 , the number of publications in biomaterials was higher.

In the dynamics of publications from Ukraine there is no explicit trend. There are constant fluctuations, with the number of publications remaining small (20-30 publications annually) (Table 2).

The results of trend models for the number of publications in biomaterials are shown in Table 10.

The results of forecasting using the trend models are shown in Table 11. According to the forecast, the share of publications from Ukraine in this direction is the largest of all considered $(0.3 \%)$.

In the whole world, starting with 2011-2012, there has been recorded a slowdown in the number of publications in all areas, except for biomaterials. This may indicate a certain exhaustion of scientific approaches and the absence of breakthrough research in these areas. A negative factor is the absence of upward trend in the number of publications from Ukraine in all directions. In combination with a small share of Ukraine in the global space of biotechnological research, this is an indicator of unsatisfactory scientific support for the introduction of biotechnology in various fields of activity in the country and poses a risk of deepening the technological lag behind the leading countries.

To identify the common features of biotechnology research in Ukraine and in the world, a correlation analysis of the number of publications in the areas has been carried out.

The correlation coefficients between the number of publications originating from Ukraine, from the EU countries, and from the whole world in international periodicals are shown in Table 12. The highest correlation is observed between the number of Ukrainian publications in chemical engineering and the number of publications from the EU countries and the whole world in all research areas. Less, but above-the-average correla- 
tion is observed between the Ukrainian publications in biomedical engineering and in the other directions, both the publications from the $\mathrm{EU}$ countries and the world ones. The average correlation is reported between the publications of Ukrainian researchers, in particular, on biotech- nology and on all directions and the publications across the EU countries and the world as a whole. It should be noted that the highest correlation is reported between the Ukrainian publications in biotechnology and the global and EU publications in immunology and microbiology - applied

Trend Models of the Number of New Publications in Material Science - Biomaterials

Table 10

\begin{tabular}{|c|c|}
\hline Country & Model \\
\hline United Kingdom & $\begin{array}{c}Y_{\text {United Kingdom }}^{\text {biomaterial }}(t)=341.80 /(0.402+\exp (-0.224 \cdot t)), \\
R^{2}=0.96 ; S t_{1}=8.39 ; S t_{2}=8,97 ; S t_{3}=-5.71 ; F=965.40 ; M A P E=6,4 \%(\text { with out } 2008,2011)\end{array}$ \\
\hline Germany & $\begin{array}{c}\mathrm{Y}_{\text {Germany }}^{\text {biomateral }}(t)=245.100 /(0.2309+\exp (-0.2748 \cdot t)) \\
R^{2}=0.95 ; S t_{1}=4.95 ; S t_{2}=5.96 ; S t_{3}=-5.60 ; F=552.15 ; M A P E=7.6 \%\end{array}$ \\
\hline Total for the EU countries & $\begin{array}{c}\mathrm{Y}_{\mathrm{EU}}^{\text {biomaterial }}(t)=1667.552 /(0.329+\exp (-0.274 \cdot t)) \\
R^{2}=0.95 ; S t_{1}=4.79 ; S t_{2}=5.33 ; S t_{3}=-4.70 ; F=485.24 ; M A P E=6.9 \%\end{array}$ \\
\hline India & $\begin{array}{c}\mathrm{Y}_{\text {India }}^{\text {biomatial }}(t)=74.935 \cdot \exp (0.162 \cdot t) \\
R^{2}=0.99 ; S t_{1}=14.05 ; S t_{2}=29.12 ; F=2021.72 ; M A P E=7.3 \%\end{array}$ \\
\hline China & $\begin{array}{c}\mathrm{Y}_{\text {China }}^{\text {biomaterial }}(t)=313.092 \cdot \exp (0.170 \cdot t) \\
R^{2}=0.98 ; S t_{1}=3.24 ; S t_{2}=17.99 ; F=753.41 ; M A P E=10.8 \%\end{array}$ \\
\hline Korea & $\begin{array}{c}\mathrm{Y}_{\text {Korea }}^{\text {biomaterial }}(t)=105.533 \cdot \exp (0.1516 \cdot t) \\
R^{2}=0.97 ; S t_{1}=5.45 ; S t_{2}=4.78 ; F=589.77 ; M A P E=10.4 \%\end{array}$ \\
\hline USA & $\begin{array}{c}\mathrm{Y}_{\text {USA }}^{\text {biomaterial }}(t)=851.651 /(0.2477+\exp (-0.267 \cdot t)) \\
R^{2}=0.94 ; S t_{1}=5.02 ; S t_{2}=5.77 ; S t_{3}=-5.37 ; F=538.91 ; M A P E=6.5 \%\end{array}$ \\
\hline Japan & $\begin{array}{c}\mathrm{Y}_{\text {Japanaterial }}^{\text {bion }}(t)=-0.7995 \cdot t^{2}+22.151 \cdot t+643.08 \\
R^{2}=0.54 ; S t_{1}=-1.10 ; S t_{2}=1.96 ; S t_{3}=-18.24 ; F=1009.89 ; M A P E=6.1 \%\end{array}$ \\
\hline Ukraine & $\begin{array}{c}\mathrm{Y}_{\text {Ukraine }}^{\text {biomateral }}(t)=0.1544 \cdot t^{2}-2.227 \cdot t+33.75 \\
\left.R^{2}=0.52 ; S t_{1}=2.37 ; S t_{2}=-2.19 ; S t_{3}=10.27 ; F=175.14 ; M A P E=12.4 \% \text { (with out } 2012\right)\end{array}$ \\
\hline Total in the world & $\begin{array}{c}Y_{\text {World }}^{\text {biomatial }}(t)=2979.956+774.456 \cdot t \\
R^{2}=0.97 ; S t_{1}=8.64 ; S t_{2}=19.77 ; F=390.92 ; M A P E=6.5 \%\end{array}$ \\
\hline
\end{tabular}

Information is taken from authors' sources.

Forecast of Publications in Materials Science - Biomaterials

Table 11

\begin{tabular}{|c|c|c|c|c|c|c|c|c|c|c|}
\hline Years & $\begin{array}{c}\text { United } \\
\text { Kingdom }\end{array}$ & Germany & $\begin{array}{c}\text { Total for the } \\
\text { EU countries }\end{array}$ & India & China & Korea & USA & Japan & $\begin{array}{c}\text { Ukraine } \\
\begin{array}{c}\text { Total in the } \\
\text { world }\end{array}\end{array}$ \\
\hline 2016 & 795 & 1008 & 4883 & 1001 & 4753 & 1193 & 3255 & 793 & 38 & 15371 \\
2017 & 806 & 1020 & 4927 & 1177 & 5634 & 1389 & 3296 & 789 & 41 & 16146 \\
2018 & 814 & 1030 & 4960 & 1384 & 6677 & 1616 & 3328 & 783 & 44 & 16920 \\
2019 & 821 & 1037 & 4985 & 1627 & 7915 & 1881 & 3353 & 775 & 47 & 17695 \\
\end{tabular}

Information is taken from authors' sources. 
Results of the Correlation Analysis of the Publishing Activity in Ukraine and in the World in Biotechnological Fields

\begin{tabular}{|c|c|c|c|c|c|}
\hline \multirow[b]{2}{*}{ Field } & \multicolumn{5}{|c|}{ Ukraine } \\
\hline & $\begin{array}{l}\text { biochemistry, } \\
\text { genetics, } \\
\text { and molecular } \\
\text { biology - } \\
\text { biotechnology }\end{array}$ & $\begin{array}{c}\text { chemical } \\
\text { engineering - } \\
\text { bioengineering }\end{array}$ & $\begin{array}{c}\text { materials } \\
\text { science - } \\
\text { biomaterials }\end{array}$ & $\begin{array}{c}\text { engineering - } \\
\text { biomedical } \\
\text { engineering }\end{array}$ & $\begin{array}{c}\text { immunology and } \\
\text { microbiology - } \\
\text { applied } \\
\text { microbiology and } \\
\text { biotechnology }\end{array}$ \\
\hline $\begin{array}{l}\text { Total for the EU countries: } \\
\text { biochemistry, genetics, and molecular } \\
\text { biology - biotechnology } \\
\text { chemical engineering - bioengineering } \\
\text { materials science - biomaterials } \\
\text { engineering - biomedical engineering } \\
\text { immunology and microbiology - applied } \\
\text { microbiology and biotechnology } \\
\text { Total in the world: } \\
\text { biochemistry, genetics, and molecular } \\
\text { biology - biotechnology } \\
\text { chemical engineering - bioengineering } \\
\text { materials science - biomaterials } \\
\text { engineering - biomedical engineering } \\
\text { immunology and microbiology - applied } \\
\text { microbiology and biotechnology }\end{array}$ & $\begin{array}{l}0.518 \\
0.544 \\
0.505 \\
0.500 \\
0.619\end{array}$ & $\begin{array}{l}0.937 \\
0.924 \\
0.915 \\
0.941\end{array}$ & $\begin{array}{l}-0.112 \\
-0.222 \\
-0.194 \\
-0.145 \\
-0.141\end{array}$ & $\begin{array}{l}0.767 \\
0.667 \\
0.696 \\
0.747\end{array}$ & $\begin{array}{l}-0.365 \\
-0.340 \\
-0.347 \\
-0.308\end{array}$ \\
\hline
\end{tabular}

Note. Statistically significant correlations with a confidence level of $5 \%$ are marked with bold Information is taken from authors' sources.

microbiology and biotechnology, which indicates a certain orientation of Ukrainian scholarly research in biotechnology, in general. A barely perceptible correlation between the number of publications in biomaterials and biomedical engineering is caused by very weak trends in Ukrainian developments, which against the background of world trends can be considered almost constant.

For the analysis of world publications on biotechnological research in various fields of science, the Science Direct DB [18] has been selected. It covers 3,800 scholarly research journals and more than 35,000 books published by Elsevier Publishing House and has the lion's share of those included in the Scopus DB. The number of publications is over 14 million.

The analysis used the search for keyword "biotech", as it covers the largest number of morphological and derivative forms. To exclude the pub- lications in which biotechnology was the main subject of the study, the search was carried out only in the title, keywords, and annotations. Therefore, the number of publications was small as compared with the previous results. The search was carried out in separate areas of sciences, in which the most common are developments in biotechnology.

The dynamics of the number of publications on biotechnology are shown in Fig. 1.

As the Figure shows, the dynamics of the number of publications are characterized by a weak upward trend. There is a four-year cycle that is likely associated with certain events (conferences, symposiums) or publication of series.

A rapid increase in the number of publications in 2004 was caused by booming publications on biotechnology in pharmacology, toxicology, and pharmaceutics, as well as in the field of sports and 


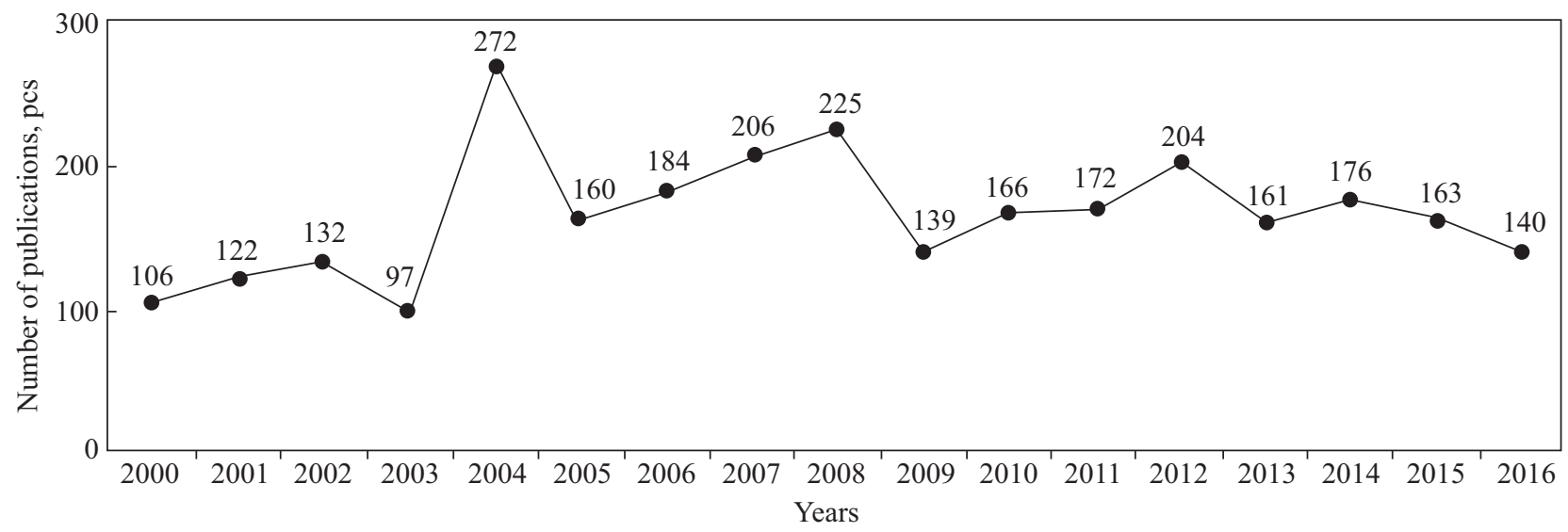

Fig. 1. Number of publications related to biotechnology according to the data from Science Direct DB [18]

Fig. 2. Structure of publications related to biotechnology by the fields of science: 1 - sports and recovery; 2 - biochemistry, genetics, and molecular biology; 3 - medicine and dentistry; 4 - chemical engineering; 5 - pharmacology, toxicology, and pharmaceuticals; 6 immunology and microbiology; 7 agricultural and biological sciences; 8 - business, management, and economics; 9 - chemistry; 10 - material science; 11 - engineering; 12 neurology; 13 - veterinary medicine; 14 - energy

According to the Science Direct database [18].

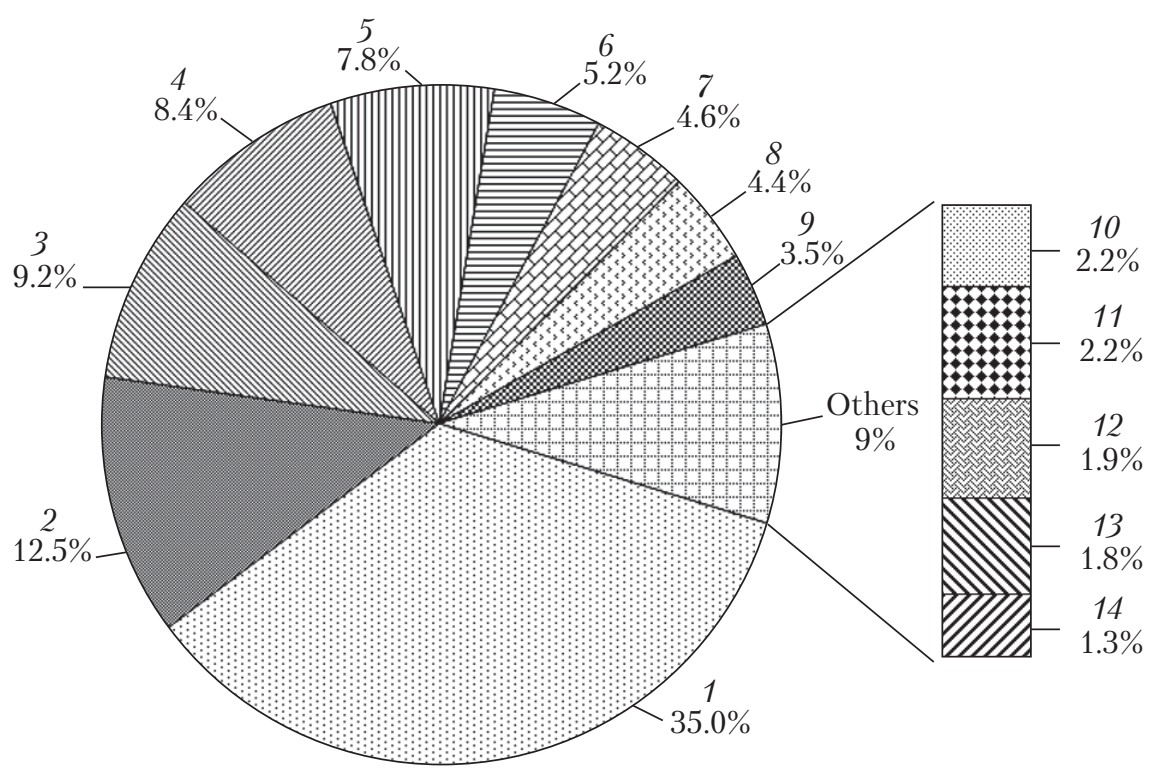

recovery. In other areas, the annual number of publications varied slightly.

According to the total data for 2000-2016, the structure of publications on biotechnology in certain areas of sciences has been determined (Fig. 2). The publications in sports and recovery, biochemistry, genetics, and molecular biology, and medicine and dentistry have the largest share. Such a large share of publications on the use of biotechnology in sports is associated with a significant interest in the use of various nutritional supplements and methods of reconstructive medicine and rehabilitation. The share of this field increased from 36\%, in 2004, to 39.3\%, in 2015 . This growth was accompanied with a rapid development of research in this direction.

The publications on the use of biotechnology in agriculture have a small share during the whole period under consideration (4.6\%). However, in 2015 , the share of these publications reached $7.4 \%$, indicating an increase in interest in research on agricultural biotechnology.

The analysis of the publication activity of Ukrainian researchers in biotechnology was based on the data from the Vernadsky National Library of Ukraine (VNLU) abstract database [19]. 


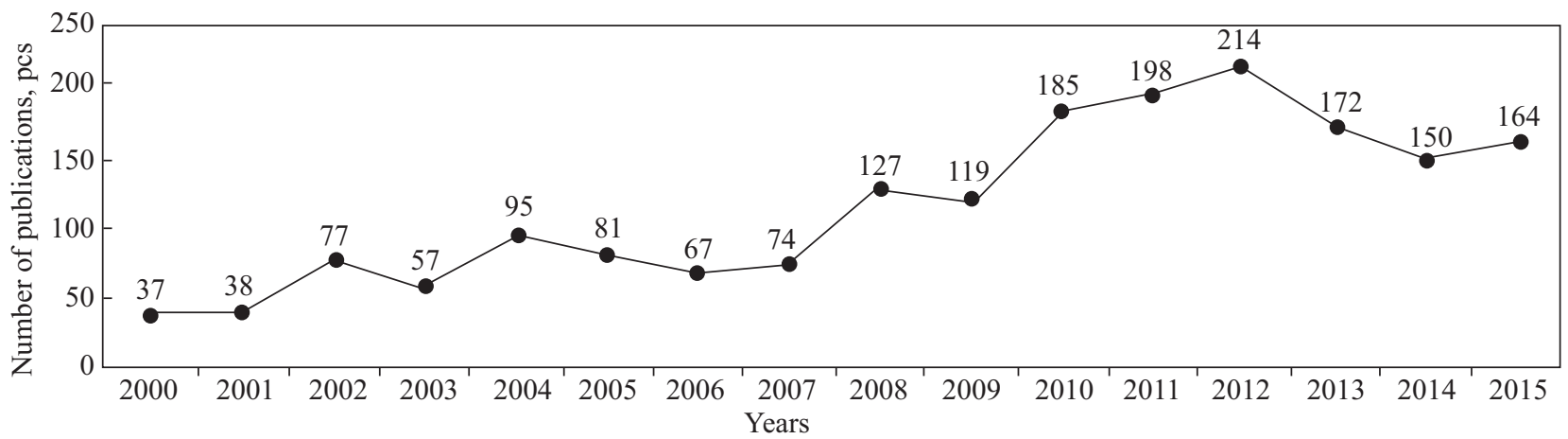

Fig. 3. Number of publications in Ukraine related to biotechnology, according to the Vernadsky National Library of Ukraine (VNLU) abstract database [19]

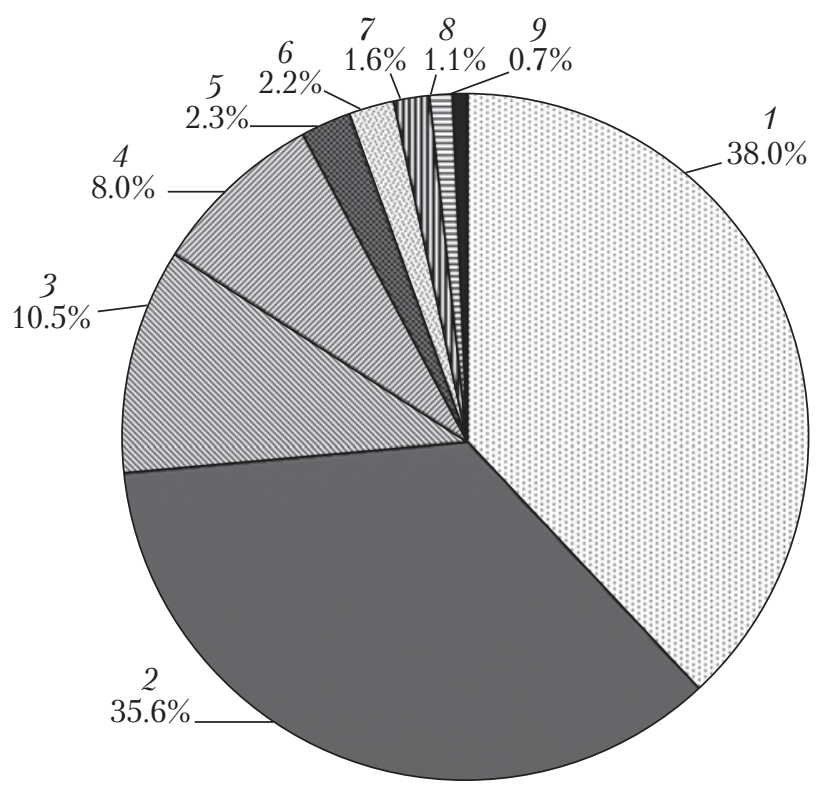

Fig. 4. Structure of publications in Ukraine related to biotechnology, by branches of knowledge: 1 - agriculture and forestry; 2 - biological sciences; 3 - medicine, medical sciences; 4 - chemical technology, chemical, and food production; 5 - economics; 6 - chemical sciences; 7 - power engineering, radio electronics; 8 - general engineering work; 9 - others (earth science, sports)

According to the Vernadsky National Library of Ukraine abstract database [19].

To identify the publications related to the development, use, and other issues of biotechnology, a search was made in the abstract database [19] by requesting $\$$ biotech $\$$, which enabled to search in various morphological forms derived from the concept of "biotechnology". The results were grouped by publication and knowledge sectors.
The dynamics of the total number of publications related to biotechnology are shown in Fig. 3. According to the received data, the scientific interest in biotechnology in Ukraine as a whole has been increasing. A fall in the number of publications in 2013-2015 as compared with 2012 is largely caused by negative trends and crisis in the socio-economic state of the country.

The fastest growth in the number of publications was reported in 2008, when it increased 1.71 times, with average annual growth rate of publications being $13.9 \%$, in $2008-2012$. The positive fact is that in 2015 , the number of publications increased in comparison with 2014, which gives a reason to talk about renewal of scholarly research in biotechnology.

For the analysis and forecast of dynamics, the linear model is the most adequate:

$$
\begin{gathered}
\left.\mathrm{Y}_{\mathrm{Ukraine}}^{\mathrm{VNLU}}(t)=35.765+10.6897 \cdot t\right), \\
R^{2}=0.76 ; S t_{1}=2.54 ; S t_{2}=6.70 ; \\
F=44.87 ; M A P E=20.3 \% .
\end{gathered}
$$

A high level of the mean absolute percentage error is explained, first of all, by significant deviations from the trend line in 2006-2007 and in 2011-2012. These deviations have a significant impact against the background of a small number of observations. However, it is impossible to establish the existence of more complex cyclic dynamics, since even two complete cycles have not been observed. 
The analysis of publications in the Ukrainian scholarly research periodicals was carried out according to the branches of knowledge in order to identify the areas of research in which scholarly research achievements are the largest. When choosing those fields of knowledge in which publications were searched, the data from the above research on the analysis of publications in different directions in the Science Direct database was used. The results of the analysis are shown in Fig. 4.

As shown in Fig. 4, the largest number of publications on biotechnology in Ukraine carried out in 2000-2015 belongs to agricultural sciences (including forestry). The publications in the field of medicine have a share of only $10.5 \%$. However, there are some changes in the structure of publications in certain branches of science. Thus, in comparison with 2004, the share of publications in agricultural sciences has decreased from 51 to $41.6 \%$, in 2015 , but still remains the largest one. Instead, the share of publications on general biotechnology issues in biological sciences has increased from 13\%, in 2004, to $28.9 \%$, in 2015 . This may indicate the development of fundamental research in this direction.

The negative fact is that the share of publications in the field of medicine declined from $14 \%$ to $11 \%$, which was caused by a fall of almost

Trend Models for the Number of Published Patents

Table 14 in Biotechnology by Applicant's Origin

\begin{tabular}{|c|c|}
\hline Country & Model \\
\hline World (without China) & $\begin{array}{c}Y_{\text {World }}=32819.57 \cdot e^{0.03} \\
R^{2}=0.96 ; t_{1}=50.86 ; t_{2}=9.77 ; F=6986.00 ; M A P E=1.74 \%\end{array}$ \\
\hline EU (28) & $\begin{array}{c}Y_{E U}(t)=9433.53 \cdot t^{0.107} \\
R^{2}=0.66 ; t_{1}=21.45 ; t_{2}=4.95 ; F=2180.10 ; M A P E=4.80 \%\end{array}$ \\
\hline USA & $\begin{array}{c}Y_{U S A}(t)=12217.5 \cdot e^{0.03} \\
R^{2}=0.80 ; t_{1}=26.03 ; t_{2}=5.72 ; F=1869.69 ; M A P E=3.97 \%\end{array}$ \\
\hline China & $\begin{array}{c}Y_{\text {China }}(t)=732.16 \cdot e^{0.1866 \cdot t} \\
R^{2}=0.98 ; t_{1}=8.35 ; t_{2}=21.92 ; F=1070.99 ; M A P E=19.41 \%\end{array}$ \\
\hline Japan & $\begin{array}{c}Y_{\text {Japan }}(t)=494.58 \cdot \ln (t)+3247.6 \\
R^{2}=0.71 ; t_{1}=5.63 ; t_{2}=18.40 ; F=1985.08 ; M A P E=6.40 \%\end{array}$ \\
\hline Korea & $\begin{array}{c}Y_{\text {Korea }}(t)=839.22 \cdot e^{0.0806 \cdot t} \\
R^{2}=0.98 ; t_{1}=22.26 ; t_{2}=21.98 ; F=2373.31 ; M A P E=5.95 \%\end{array}$ \\
\hline Switzerland & $\begin{array}{c}Y_{\text {Switzerland }}(t)=702.06 \cdot e^{0.077 \cdot t} \\
R^{2}=0.97 ; t_{1}=21.16 ; t_{2}=19.81 ; F=2061.91 ; M A P E=5.97 \%\end{array}$ \\
\hline France & $\begin{array}{c}Y_{\text {France }}(t)=1260.62 \cdot e^{0.035 \cdot t} \\
R^{2}=0.79 ; t_{1}=19.45 ; t_{2}=7.33 ; F=1122.99 ; M A P E=7.26 \%\end{array}$ \\
\hline Netherlands & $\begin{array}{c}Y_{\text {Netherlands }}(t)=40.65 \cdot t+688.3 \\
R^{2}=0.92 ; t_{1}=12.81 ; t_{2}=22.44 ; F=2581.67 ; M A P E=4.31 \%\end{array}$ \\
\hline Denmark & $\begin{array}{c}Y_{\text {Denmark }}(t)=46.77 \cdot t+449.4 \\
R^{2}=0.96 ; t_{1}=17.28 ; t_{2}=17.17 ; F=2453.66 ; M A P E=4.42 \%\end{array}$ \\
\hline Ukraine & $\begin{array}{c}Y_{\text {Ukraine }}(t)=11.45 \cdot \ln (t) \\
R^{2}=0.77 ; t_{1}=18.20 ; F=331.39 ; M A P E=24.28 \%\end{array}$ \\
\hline
\end{tabular}

Information is taken from authors' sources. 
Poliakova, O.Yu., Shlykova, V.O., and Buntov, I.Yu.

Number of Published Patents in Biotechnology by Applicant's

\begin{tabular}{|c|c|c|c|c|c|}
\hline \multirow{2}{*}{ Country } & \multicolumn{4}{|c|}{ Years } & \multirow{2}{*}{$\begin{array}{c}\text { Share for } \\
2016-2019, \%\end{array}$} \\
\hline & 2016 & 2017 & 2018 & 2019 & \\
\hline World & 63120.3 & 68094.3 & 73845.8 & 80527 & 100 \\
\hline EU (28) & 12774 & 12853 & 12927 & 12998 & 18.1 \\
\hline China & 17469.3 & 21053 & 25371.9 & 30576.9 & 33.1 \\
\hline USA & 16994.78 & 17512.35 & 18045.68 & 18595.25 & 24.9 \\
\hline Japan & 4648.851 & 4677.12 & 4703.861 & 4729.229 & 6.6 \\
\hline Korea & 3303 & 3581 & 3881 & 4207 & 5.2 \\
\hline Germany & $3465( \pm 94)$ & $3465( \pm 94)$ & $3465( \pm 94)$ & $3465( \pm 94)$ & 4.9 \\
\hline Switzerland & 2599 & 2807 & 3032 & 3275 & 4.1 \\
\hline France & 2286 & 2367 & 2451 & 2539 & 3.4 \\
\hline UK & $1548( \pm 113)$ & $1548( \pm 113)$ & $1548( \pm 113)$ & $1548( \pm 113)$ & 2.2 \\
\hline Netherlands & 1379 & 1420 & 1461 & 1501 & 2.0 \\
\hline Denmark & 1244 & 1291 & 1338 & 1385 & 1.8 \\
\hline Ukraine & 32 & 33 & 34 & 34 & 0.05 \\
\hline
\end{tabular}

Information is taken from authors' sources.

1.5 times in the number of publications in this direction. In the field of sports for the whole period under consideration, only 7 publications were published at all, indicating a poor development in this field.

The presence of interest in biotechnology as a source of economic growth and development is evidenced by a relatively large number of publications on economics, with this interest growing starting with 2012.

Due to a small number of publications on biotechnology in particular branches of science, predictive models have not been built for them.

The trend models for obtaining predictive values of the number of patents have been developed based on WIPO database as of September 2017 for the world, EU (28), the ten leading countries by the number of published patents, and Ukraine [20]. The equations with the highest quality indicators, their characteristics, and average absolute error forecast are presented in Table 14.

The equation of trend for the U.S. applicants published patents (Table 14) is based on the data for the period 2006-2015, since the period 20002005 is characterized by a fundamentally different trend.
The retrospective data on published patents by the German applicants have not enabled to identify a stable trend. A rapid growth in 2000-2003 was followed by a decrease in 2004-2006, after which the dynamics were abrupt with the fluctuations around the average. At the same time, Germany is among the leaders in terms of the absolute indicators. It has not been possible to build a trend for British published patents. Therefore, these countries are supposed to keep the number of patents at the average level (2006-2015) with fluctuations within the standard deviation.

For Japan and Ukraine, the time series were preprocessed using exponential smoothing.

The forecast model for the world is built without data for China, as the growth rate of patented developments of Chinese origin in biotechnology significantly exceeds that in the rest of the world. Then, the predicted values for China are summed with the values obtained for the whole world. This has enabled to determine more accurately the share of patents for each leading country in the periods of forecast.

Based on the assumptions made for the models, calculations of the corresponding predictive values have been made (Table 15). 


\section{CONCLUSIONS}

The results of the forecast have shown an upward trend in the number of patents on biotechnological developments in the world in the upcoming years. The EU member states as a whole and its leading countries, in particular, are characterized by moderate growth rates, whereas China and Korea are demonstrating a rapid growth. The patenting of Ukrainian developments at the international level, provided the current situation stays unchanged, will remain at a very low level, namely $0.05 \%$ on a global scale. China and the USA will keep leadership in this direction with shares of 33.1 and $24.9 \%$, respectively. The total number of EU (28) patents will be about $18.1 \%$.

Having compared the distribution of publications in international databases and the national abstract database enables to determine that the trends in the development of scholarly research in Ukraine differ significantly from the world- wide ones. The vast majority of publications is related to the field of agriculture while much less, as compared with the world practice, attention is paid to the use of biotechnology in medicine and pharmaceuticals. In the field of energy, research on biotechnology has not yet become widespread both in Ukraine or worldwide.

Thus, based on the results of comparative analysis of publishing activity in Ukraine and in the world, it can be noted that Ukraine has certain progress in the development of biotechnology in agriculture, which can become the basis for the development of the national bio-economy. Consequently, in the agricultural sector, government support is needed for the implementation of existing developments by encouraging business.

At the same time, in the medical field, there is a significant gap with the leading countries, thus government efforts should focus on supporting research in this area in order to bring the $R \& D$ results to the stage of readiness for patenting.

\section{REFERENCES}

1. Dalpé, R. (2002). Bibliometric analysis of biotechnology. Scientometrics, 55, 2, 189-213.

2. Jiancheng, Guan, Xia Gao. (2008). Comparison and evaluation of Chinese research performance in the field of bioinformatics. Scientometrics, 75(2), 357-379. DOI: 10.1007/s11192-007-1871-0

3. Meyer, M. (2006). Measuring science-technology interaction in the knowledge-driven economy: The case of a small economy. Scientometrics, 66(2), 425-439.

4. Van Raan, A. F. J. (1999). Advanced bibliometric methods in the analysis of research performance and scientific developments: a contribution to science policy in transition countries. In: D.A. Dyker and S. Radosevic (Editors). Innovation and structural change in post-socialist countries: A quantitative approach. NATO ASI Series, 4. Science and Technology Policy, vol. 20. Dordrecht: Kluwer Academic Publishers, 89-105.

5. Borisova, L. F., Bogacheva, N. S., Markusova, V. A., Suetina, E. E. (2007). Bionanotechnhology: A Bibliometric Analysis Using Science Citation Index Database (1995-2006). Scientific and Technical Information Processing, 34(4), $212-218$.

6. Hullmann, A., Meyer, M. (2003). Publications and patents in nanotechnology. An overview of previous studies and the state of the art. Scientometrics, 58(3), 507-527.

7. Hinze, S., Grupp, H. (1996). Mapping of R\&D structures in transdisciplinary areas: new biotechnology in food sciences. Scientometrics, 37(2), 313-335.

8. Korzhavykh, E. A. (2012). Scientometric Assessment of the Progress of Innovative Pharmacy in Russia. Russian Journal of General Chemistry, 82(3), 527-534.

9. Calero, C., van Leeuwen, T. N., Tijssen, R. J. W. (2007). Research cooperation within the bio-pharmaceutical industry: Network analyses of co-publications within and between firms. Scientometrics, 71(1), 87-99. DOI: 10.1007/s11192-007-1650-y.

10. Choi, J., Jun, S., Park, S. (2016). A Patent Analysis for Sustainable Technology Management. Sustainability, 8(7), 688. URL: http://www.mdpi.com/2071-1050/8/7/688/htm (Last accessed: 03.05.2017).

11. Heeyong, Noh, Yeongran, Jo, Sungjoo, Lee (2015). Keyword selection and processing strategy for applying text mining to patent analysis. Expert Systems with Application, 42(9), 4348-4360.

12. Grimaldi, M., Cricelli, L., Di Giovanni, M., Rogo, F. (2015). The patent portfolio value analysis: A new framework to leverage patent information for strategic technology planning. Technological Forecasting and Social Change, 94, $286-302$. DOI:10.1016/j.techfore.2014.10.013 
13. Kortov, S. V., Shulgin, D. B., Tolmachev, D. E., Yegarmina, A. D. (2017). Technology trends analysis using patent landscaping. Economy of Region, 13(3), 935-947 [in Russian].

14. Sunghae, J., Sang Sung, P., Dong Sik, J. (2012). Patent Management for Technology Forecasting: A Case Study of the Bio-Industry. Journal of Intellectual Properties Rights, 17, 539-546.

15. Poliakova, O. Yu., Shlykova, V. O. (2017). The Patenting of biotechnological developments in Ukraine: trends and structure. The Problems of Economy, 2, 124-131 [in Ukrainian].

16. Specialized DB “Inventors (Utility Models) in Ukraine” / Ukrainian Intellectual Property Institute(UKRPATENT). URL: http://base.uipv.org/searchINV/ (Last accessed: 03.05.2018).

17. SCImago Journal \& Country Rank. URL: http://scimagojr.com (Last accessed: 10.02.2018).

18. Science Direct. URL: http://www.sciencedirect.com (Last accessed: 22.01.2018).

19. Vernadsky National Library of Ukraine. URL: http://nbuv.gov.ua/ (Last accessed: 19.04.2018).

20. WIPO IP Statistics Data Center / World Intellectual Property Organization. URL: https://www3.wipo.int/ipstats/index.htm (Last accessed: 03.05.2018).

Received 08.05.18

\section{О.Ю. Полякова, В.О. Шликова, І.Ю. Бунтов}

Науково-дослідний центр індустріальних проблем розвитку НАН України, пров. Інженерний, 1-А, Харків, 61166, Україна, +380 57702 0867,ndc_ipr@ukr.net; https://ndc-ipr.org/

\section{ПРОГНОЗУВАННЯ ТРЕНДІВ РОЗВИТКУ БІОТЕХНОЛОГІЙ В СВІТІ ТА УКРАЇНІ НА ОСНОВІ ПУБЛІКАЦІЙНОГО Й ПАТЕНТНОГО АНАЛІЗУ}

Вступ. Сучасні біотехнології є однією з найбільш пріоритетних галузей національної економіки розвинених країн.

Проблематика. Успішне управління розвитком технологій вимагає об'єктивного аналізу результатів наукових досліджень та їх прогнозування. Відповідність рівня технологічного розвитку країни світовим тенденціям відіграє важливу роль у забезпеченні конкурентоспроможності їі економіки.

Мета. Визначення тенденцій наукових досліджень і розробок у галузі біотехнологій та їх відмінностей в світі й Україні.

Матеріали й методи. Бібліометричний та патентний аналіз використано як найпоширеніші інструменти аналізу поточного стану, перспективних напрямів наукових досліджень і комерціалізації їх результатів. Аналіз світових та українських тенденцій публікаційної та патентної активності у сфері біотехнології за 2000-2015 рр., а також прогнозування на 2016-2019 pр. з використанням трендових моделей. Роботу здійснено на основі публікацій, пов’язаних з біотехнологіями, що містяться на порталі SCImago Journal \& Country Rank, у базі Science Direct та peферативній базі даних Національної бібліотеки України ім. В.I. Вернадського, а також патентів з бази даних World Intellectual Property Organization.

Результати. Прогнозування демонструє тенденцію до збільшення обсягу публікацій та патентів у галузі біотехнології у світі в найближчі роки. За всіма напрямами біотехнології питома вага українських публікацій у світовому просторі біотехнологічних наукових досліджень є вкрай малою. Серед аналізованих напрямів найбільша прогнозована питома вага публікацій українського походження у міжнародних базах визначена за напрямом «Матеріалознавство - біоматеріали» і становить 0,3 \% у загальносвітовому масштабі. Патентування українських розробок на міжнародному рівні, за умов збереження наявного тренду, також залишатиметься на дуже низькому рівні, а саме 0,05 \% у світовому масштабі. Лідерство за цим напрямом зберігатиметься за Китаєм та США із частками 33,1 та 24,9% відповідно, загальна кількість патентів країн ЄС становитиме близько 18,1%.

Висновки. На сьогодні Україна має певні переваги у розвитку біотехнологій у галузі сільського господарства, які можуть стати основою для розвитку біоекономіки країни. Отже, в аграрній сфері необхідною є державна підтримка впровадження наявних розробок шляхом заохочення бізнесової діяльності. У той же час у медицині спостерігається значне відставання від провідних країн світу, тому зусилля держави повинні зосереджуватися на підтримці проведення досліджень у цій галузі та доведення розробок до стадії готовності для патентування.

Ключові слова: біотехнологія, бібліометрія, патент, кореляція, тренд, прогнозна модель. 


\section{О.Ю. Полякова, В.А. Шльюкова, И.Ю. Бунтов \\ Научно-исследовательский центр индустриальных проблем развития НАН Украины, пер. Инженерный, 1-А, Харьков, 61166, Украина, +380 57702 0867,ndc_ipr@ukr.net; https://ndc-ipr.org/ \\ ПРОГНОЗИРОВАНИЕ ТРЕНДОВ РАЗВИТИЯ БИОТЕХНОЛОГИЙ В МИРЕ И УКРАИНЕ НА ОСНОВЕ ПУБЛИКАЦИОННОГО И ПАТЕНТНОГО АНАЛИЗА}

Введение. Современные биотехнологии являются одним из приоритетных секторов национальной экономики для развитых стран мира.

Проблематика. Успешное управление развитием технологий требует объективного анализа результатов научных исследований и их прогнозирования. Соответствие уровня технологического развития страны мировым тенденциям играет важную роль в обеспечении конкурентоспособности экономики.

Цель. Определение тенденций научных исследований и разработок в области биотехнологии и их отличий в мире и Украине.

Материалы и методы. Библиометрический и патентный анализ использованы как наиболее распространенные инструменты анализа текущего состояния, перспективных направлений научных исследований и коммерциализации их результатов. Анализ мировых и украинских тенденций публикационной и патентной активности в сфере биотехнологии за 2000-2015 гг., а также прогнозирование на 2016-2019 гг. с использованием трендовых моделей. Роботу проводили на основании публикаций, связанных с биотехнологиями, размещенных на портале SCImago Journal $\mathcal{E}$ Country Rank, базы Science Direct и реферативной базы данных Национальной библиотеки Украины им. В.И. Вернадского, а также патентов в базе данных World Intellectual Property Organization.

Результаты. Прогнозирование демонстрирует тенденцию к увеличению количества публикаций и патентов в сфере биотехнологий в мире в ближайшие годы. По всем направлениям биотехнологии удельный вес украинских публикаций в мировом пространстве биотехнологических научных исследований крайне низок. Среди проанализированных направлений самый высокий спрогнозированный удельный вес имеют публикации украинского происхождения в международных базах по направлению «Материаловедение - биоматериалы», который составляет 0,3 \% в общемировом масштабе. Патентование украинских разработок на международном уровне, при сохранении имеющегося тренда, также будет оставаться на очень низком уровне, а именно 0,05 \% в мировом масштабе. Лидерами по этому направлению останутся Китай и США с долями 33,1 и 24,9 \% соответственно, общее количество патентов стран ЕС составит около 18,1\%.

Выводы. На сегодня Украина имеет определенные преимущества в развитии биотехнологий в области сельского хозяйства, которые могут стать основой для развития биоэкономики страны. Таким образом, в аграрной сфере необходима государственная поддержка внедрения имеющихся разработок путем поощрения бизнеса. В то же время в медицине наблюдается существенное отставание от ведущих стран мира, поэтому усилия государства должны быть сосредоточены на поддержке проведения исследований в этой области и доведения разработок до стадии готовности к патентованию.

Ключевые слова: биотехнология, библиометрия, патент, корреляция, тренд, прогнозная модель. 